\title{
VALUABLE ROADSIDE TREE AVENUES IN THE NORTH-EASTERN PART OF THE DRAWSKI LANDSCAPE PARK
}

\author{
Radoseaw Grzegorczyk, Anna Sigiel-Dopierała, Marcin K. Dyderski, Andrzej M. Jagodziński
}

R. Grzegorczyk, A. Sigiel-Dopierała, Regional Directorate of Environmental Protection in Szczecin, Department in Złocieniec, Dworcowa 13, 78-520 Złocieniec, Poland, e-mail: radoslaw.grzegorczyk. szczecin@rdos.gov.pl, anna.sigiel-dopierala.szczecin@rdos.gov.pl

M.K. Dyderski, Faculty of Forestry, Poznań University of Life Sciences, Wojska Polskiego 71 D, 60-625 Poznań, Poland, e-mail: Marcin.Dyderski@gmail.com

A.M. Jagodziński, corresponding author, Department of Forest Protection, Poznań University of Life Sciences, Wojska Polskiego 71 C, 60-625 Poznań, Poland; Institute of Dendrology, Polish Academy of Sciences, Parkowa 5, 62-635 Kórnik, Poland, e-mail: amj@man.poznan.pl

(Received: March 11, 2015. Accepted: April 10, 2015)

\begin{abstract}
The paper describes species composition and state of preservation of five roadside tree avenues situated in the north-eastern part of the Drawski Landscape Park and its buffer zone. The inventory was based on tree species identification, measurements of their diameter at breast height, and estimation of health status of stems, crowns and foliage. In total, 1488 trees from the following taxa were found: Acer platanoides, Acer pseudoplatanus, Acer pseudoplatanus 'Purpureum', Betula pendula, Fagus sylvatica, Fraxinus excelsior, Fraxinus pennsylvanica, Quercus robur and Tilia cordata. The most frequently occurring species were: Acer platanoides, Acer pseudoplatanus and Fraxinus excelsior. In roadside tree avenues high numbers of trees with monumental diameters ( 275 trees, $18.5 \%$ ) were found. Estimation of health status shows that most trees are in good condition (up to $10 \%$ of damages). In all roadside avenues discontinuities and the presence of branch deadwood have been recorded resulting from a lack of supplementary planting and inappropriate treatment. All studied avenues have high landscape and environmental values, therefore should be protected as nature monuments.
\end{abstract}

KEY WORDS: epiphytes, state of health, roadside green, cultural heritage, nature monuments

\section{INTRODUCTION}

Roadside tree avenues are buffer strips which occur adjacent to roads. Most frequently they occur as one or a couple of tree rows. Their role in landscape is broad: avenues highlight landscape's linearity, facilitate orientation in the field, compose views and compositional axes, and increase landscape aesthetics which may promote tourism. Avenues are also considered historical and cultural heritage in local scale (Witkoś-Gnach \& Tyszko-Chmielowiec 2014). From an ecological viewpoint, avenues increase localised water retention, prevent water and wind erosion and form ecological corridors for many species (RuciŃsKi 1998, OleKsA et al. 2006, Kubus 2008, 2010, LiżEWSKA \& Zwierowicz 2009, Podolska 2013).

Avenues are also habitats for several groups of species (Witkoś-Gnach \& Tyszko-Chmielowiec 2014).
For example, in old trees with hollows, many species of protected insects may be found. The most precious of them are Natura 2000 priority species Osmoderma eremita and Cerambyx cerdo (OLEKSA et al. 2012). OrŁowsKa (2012) found that roadside avenues can provide habitats for 43 species of birds, including woodpeckers (Picidae) and owls (Strigiformes). Trees in old avenues are often colonised by lichens (Lichenes) as their wide diameters and fissured bark provide suitable habitats for them; additionally the amount of sunlight in avenues is higher than in forests (LIPNICKI 2003, OleKSA 2012). On such trees rare and/or protected species of fungi (e.g. Fistulina hepatica, Grifola frondosa or Geastrum striatum) have been observed (Kujawa 2012).

Avenues are threatened by increasing communication pressure and route modernisations. Roadside tree removal occurs primarily to facilitate road 
widening, increasing driver visibility, traffic flow and overall road safety (PoDOLSKA 2013). Some trees also suffer from increasing air pollution and mechanical damage (GAMrat et al. 2011). Utility line construction and maintenance often results in asymmetrical crown removal which negatively affects avenue habitats and tree stability. Other factors which threaten avenues include natural dieback of trees, removal of old and unhealthy trees and lack of supplemental plantings (PoDOLSKA 2013). One conservation method to ensure the longevity of the most precious objects as nature monuments is legal protection. In 2013, 735 avenues were listed as nature monuments in Poland (Ochrona środowiska 2014).

The aim of the study was to provide an inventory of tree species composition and state of preservation of five roadside tree avenues in the north-eastern part of the Drawski Landscape Park and in its buffer zone.

\section{MATERIAL AND METHODS}

The study was conducted in the Drawski Landscape Park (DLP), located in NW Poland, between four towns: Połczyn Zdrój, Łubowo, Czaplinek and
Złocieniec. DLP covers an area of 38360.17 ha and the buffer zone around DLP covers an area of 23560.41 ha (Ochrona ŚROdOWISKA 2014, UCHWAEA... 2014). The history of planting avenue trees dates back to the 18th century, when Prussian kings Frederick William I and Frederick II the Great ordered the introduction of roadside tree plantings and introduced penalty for their destruction (KuBus 2008). In the DLP three roadside tree avenues are protected by law as nature monuments, and 11 are planned to be protected. For this study five avenues were chosen: Prosino-Stare Gonne, Kocury-Brusno, Brusno-Popielewo, Kocury-Brusno planned nature monument and 'Brusno' nature monument tree avenue (Fig. 1, Table $1)$.

Field work was conducted in 2013. The length of each avenue, distances between trees as well as between roadside and trees were measured. Each tree's diameter was measured at breast height (DBH) and state of health was assessed based on percentage of damage to individual tree components: foliage (foliage area), crown branches and stems (circumference) in six class scale: 0 - no damages, 1 - damages up to $10 \%, 2$ - damages on 11-25\%, 3 - damages on

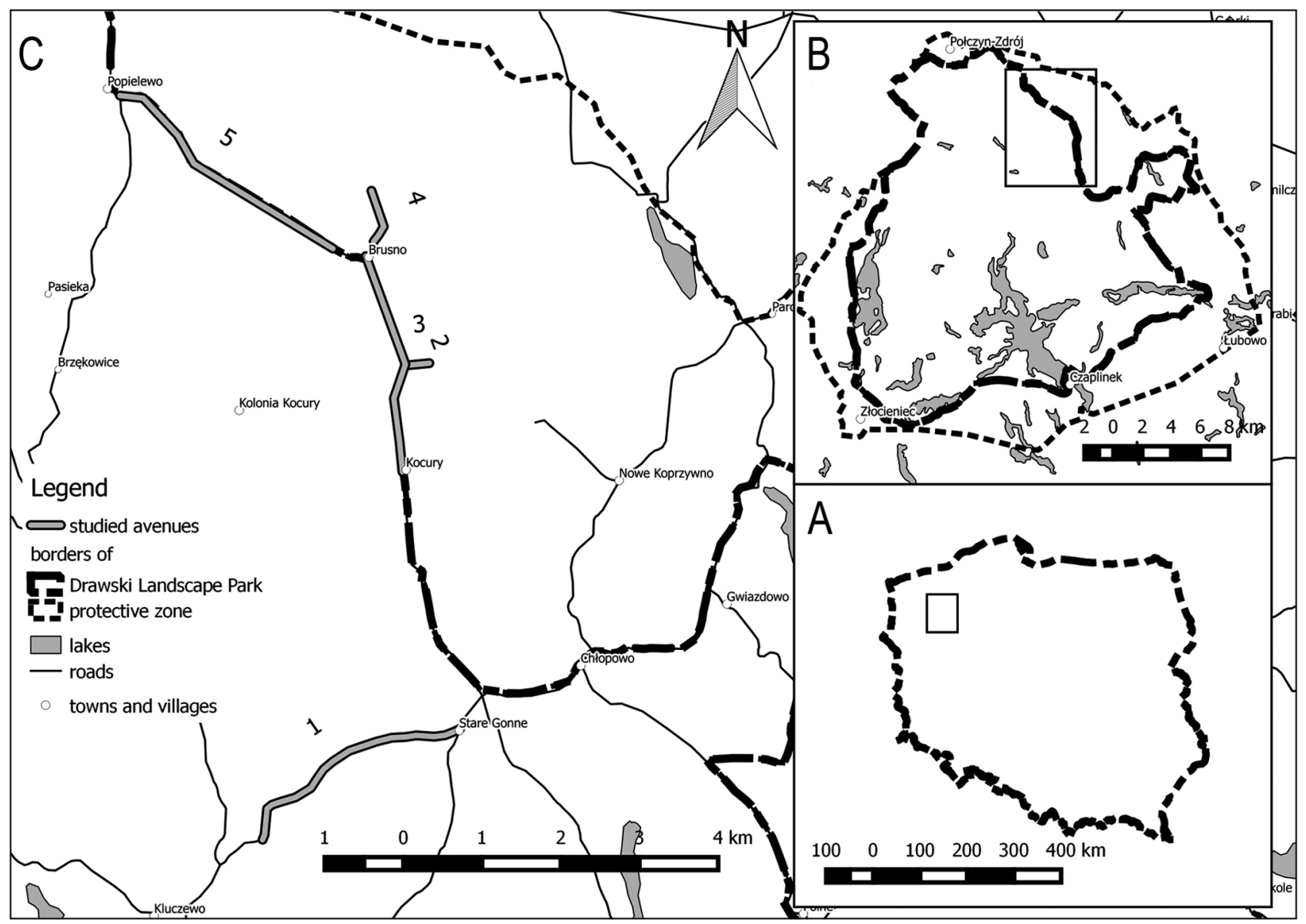

Fig. 1. Locality of tree avenues studied: A - location of the Drawski Landscape Park in Poland, B - boarders of the Drawski Landscape Park, C - localities of avenues studied in the north-eastern part of the Drawski Landscape Park. Numbers of avenues: 1 - Prosino-Stare Gonne, 2 - Kocury-Brusno, 3 - planned nature monument Kocury-Brusno, 4 - nature monument 'Brusno', 5 - Brusno-Popielewo 
26-50\%, 4 - damages on 51-75\%, 5 - damages over $75 \%$ (Kosmala et al. 2009). The health assessment was performed visually during the inventory. Due to differences in the length of tree avenues between left

and right side of the road, these sides were analysed separately. Minimal DBH for precious trees (nature monuments) were taken from RucIŃskI’s (1998) list for semi-natural sites.

Table 1. Geographical coordinates of studied tree avenues in north-eastern part of the Drawski Landscape Park

\begin{tabular}{llll}
\hline \multicolumn{1}{c}{ Avenue } & \multicolumn{1}{c}{ Side } & Beginning of the avenue & \multicolumn{1}{c}{ End of the avenue } \\
\hline Brusno-Popielewo & left & $53^{\circ} 43^{\prime} 36.7^{\prime \prime} \mathrm{N}, 16^{\circ} 13^{\prime} 04.2^{\prime \prime} \mathrm{E}$ & $53^{\circ} 44^{\prime} 35.8^{\prime \prime} \mathrm{N}, 16^{\circ} 10^{\prime} 32.0^{\prime \prime} \mathrm{E}$ \\
& right & $53^{\circ} 43^{\prime} 37.0^{\prime \prime} \mathrm{N}, 16^{\circ} 13^{\prime} 03.0^{\prime \prime} \mathrm{E}$ & $53^{\circ} 44^{\prime} 35.8^{\prime \prime} \mathrm{N}, 16^{\circ} 10^{\prime} 32.9^{\prime \prime} \mathrm{E}$ \\
Prosino-Stare Gonne & left & $53^{\circ} 39^{\prime} 35.3^{\prime \prime} \mathrm{N}, 16^{\circ} 12^{\prime} 26.9^{\prime \prime} \mathrm{E}$ & $53^{\circ} 40^{\prime} 20.2^{\prime \prime} \mathrm{N}, 16^{\circ} 14^{\prime} 35.2^{\prime \prime} \mathrm{E}$ \\
& right & $53^{\circ} 39^{\prime} 33.0^{\prime \prime} \mathrm{N}, 16^{\circ} 12^{\prime} 25.6^{\prime \prime} \mathrm{E}$ & $53^{\circ} 40^{\prime} 20.7^{\prime \prime} \mathrm{N}, 16^{\circ} 14^{\prime} 38.0^{\prime \prime} \mathrm{E}$ \\
Nature monument 'Brusno' & left & $53^{\circ} 44^{\prime} 01.6^{\prime \prime} \mathrm{N}, 16^{\circ} 13^{\prime} 25.0^{\prime \prime} \mathrm{E}$ & $53^{\circ} 43^{\prime} 42.0^{\prime \prime} \mathrm{N}, 16^{\circ} 13^{\prime} 29.7^{\prime \prime} \mathrm{E}$ \\
& right & $53^{\circ} 44^{\prime} 01.5^{\prime \prime} \mathrm{N}, 16^{\circ} 13^{\prime} 25.0^{\prime \prime} \mathrm{E}$ & $53^{\circ} 43^{\prime} 41.2^{\prime \prime} \mathrm{N}, 16^{\circ} 13^{\prime} 29.3^{\prime \prime} \mathrm{E}$ \\
Planned nature monument Kocury-Brusno & left & $53^{\circ} 42^{\prime} 49.2^{\prime \prime} \mathrm{N}, 16^{\circ} 13^{\prime} 54.9^{\prime \prime} \mathrm{E}$ & $53^{\circ} 42^{\prime} 50.6^{\prime \prime} \mathrm{N}, 16^{\circ} 14^{\prime} 07.3^{\prime \prime} \mathrm{E}$ \\
& right & $53^{\circ} 42^{\prime} 49.2^{\prime \prime} \mathrm{N}, 16^{\circ} 13^{\prime} 54.9^{\prime \prime} \mathrm{E}$ & $53^{\circ} 42^{\prime} 50.6^{\prime \prime} \mathrm{N}, 16^{\circ} 14^{\prime} 07.3^{\prime \prime} \mathrm{E}$ \\
& left & $53^{\circ} 42^{\prime} 02.3^{\prime \prime} \mathrm{N}, 16^{\circ} 13^{\prime} 55.2^{\prime \prime} \mathrm{E}$ & $53^{\circ} 43^{\prime} 31.4^{\prime \prime} \mathrm{N}, 16^{\circ} 13^{\prime} 24.0^{\prime \prime} \mathrm{E}$ \\
& right & $53^{\circ} 42^{\prime} 01.9^{\prime \prime} \mathrm{N}, 16^{\circ} 13^{\prime} 55.4^{\prime \prime} \mathrm{E}$ & $53^{\circ} 43^{\prime} 27.4^{\prime \prime} \mathrm{N}, 16^{\circ} 13^{\prime} 26.7^{\prime \prime} \mathrm{E}$ \\
\hline
\end{tabular}

Table 2. Characteristics of studied tree avenues in north-eastern part of the Drawski Landscape Park

\begin{tabular}{|c|c|c|c|c|c|c|c|c|c|c|}
\hline \multirow[t]{2}{*}{ Parameter } & \multicolumn{2}{|c|}{ Brusno-Popielewo } & \multicolumn{2}{|c|}{$\begin{array}{l}\text { Prosino-Stare } \\
\text { Gonne }\end{array}$} & \multicolumn{2}{|c|}{$\begin{array}{l}\text { Nature monument } \\
\text { 'Brusno' }\end{array}$} & \multicolumn{2}{|c|}{$\begin{array}{l}\text { Planned nature } \\
\text { monument } \\
\text { Kocury-Brusno }\end{array}$} & \multicolumn{2}{|c|}{ Kocury-Brusno } \\
\hline & $\mathrm{L}$ & $\mathrm{R}$ & $\mathrm{L}$ & $\mathrm{R}$ & $\mathrm{L}$ & $\mathrm{R}$ & $\mathrm{L}$ & $\mathrm{R}$ & $\mathrm{L}$ & $\mathrm{R}$ \\
\hline Length (m) & 3500 & 3400 & 2950 & 3150 & 600 & 650 & 221 & 221 & 2790 & 2899 \\
\hline $\begin{array}{l}\text { Range of distances between } \\
\text { trees }(\mathrm{m})\end{array}$ & $5-138$ & $4-174$ & $3.5-83$ & $4-76$ & $1-110$ & $3-33$ & $5-31$ & $2-34$ & $1-49$ & $0.9-51$ \\
\hline $\begin{array}{l}\text { Range of distances between } \\
\text { trees and roadside (m) }\end{array}$ & $1-3$ & $0.5-1$ & $1-3$ & $1.5-4$ & $4-8$ & $4-12$ & $1.5-5$ & $0.5-5$ & $1-11$ & $0.5-3$ \\
\hline Range of DBH (cm) & $9-112$ & $19-124$ & $7-110$ & $20-95$ & $41-140$ & $35-165$ & $21-132$ & $13-104$ & $4-100$ & $10-100$ \\
\hline Number of trees & 237 & 225 & 175 & 223 & 43 & 53 & 21 & 21 & 252 & 238 \\
\hline
\end{tabular}

Explanations: $\mathrm{L}$ - left side of avenue, $\mathrm{R}$ - right side of avenue.

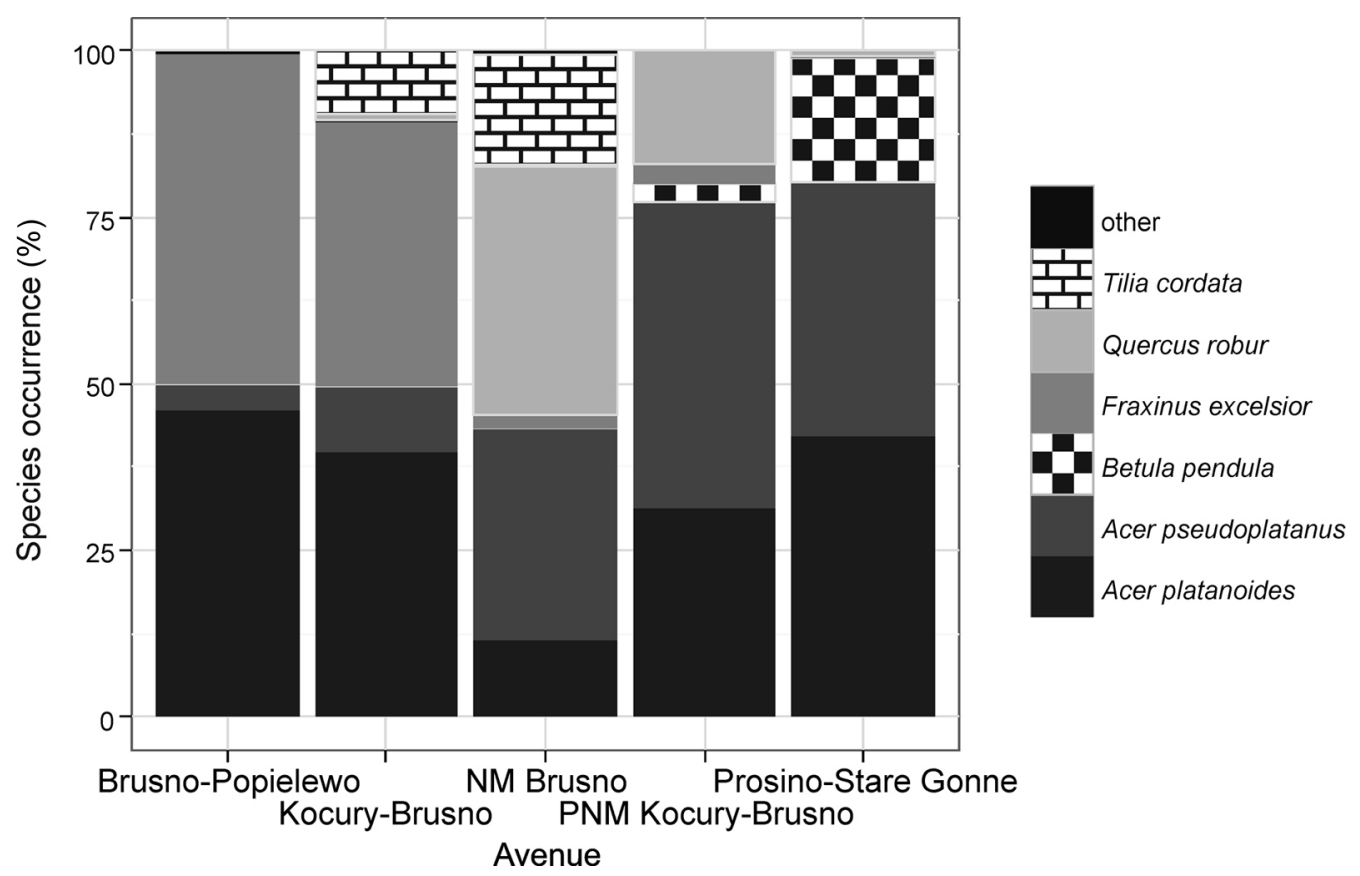

Fig. 2. Tree species occurrence in studied avenues in north-eastern part of the Drawski Landscape Park

Explanations: Acer pseudoplatanus 'Purpureum' was grouped with A. pseudoplatanus; other species are Fraxinus pennsylvanica and Fagus sylvatica, PNM - planned nature monument, NM - nature monument. 
Table 3. Number of trees from each species in studied tree avenues in north-eastern part of the Drawski Landscape Park

\begin{tabular}{|c|c|c|c|c|c|c|c|c|c|c|}
\hline \multirow[t]{2}{*}{ Tree species } & \multicolumn{2}{|c|}{ Brusno-Popielewo } & \multicolumn{2}{|c|}{$\begin{array}{l}\text { Prosino-Stare } \\
\text { Gonne }\end{array}$} & \multicolumn{2}{|c|}{$\begin{array}{c}\text { Nature monument } \\
\text { 'Brusno' }\end{array}$} & \multicolumn{2}{|c|}{$\begin{array}{l}\text { Planned nature } \\
\text { monument } \\
\text { Kocury-Brusno }\end{array}$} & \multicolumn{2}{|c|}{ Kocury-Brusno } \\
\hline & $\mathrm{L}$ & $\mathrm{R}$ & $\mathrm{L}$ & $\mathrm{R}$ & $\mathrm{L}$ & $\mathrm{R}$ & $\mathrm{L}$ & $\mathrm{R}$ & $\mathrm{L}$ & $\mathrm{R}$ \\
\hline A. platanoides & 100 & 113 & 76 & 92 & 3 & 8 & 7 & 4 & 86 & 109 \\
\hline A. pseudoplatanus & 5 & 13 & 71 & 80 & 15 & 16 & 6 & 10 & 13 & 12 \\
\hline A. pseudoplatanus 'Purpureum' & & & & & & & & & 15 & 8 \\
\hline B. pendula & & & 25 & 50 & & & & 1 & & \\
\hline F. sylvatica & & & & & 1 & & & & & \\
\hline F. excelsior & 130 & 99 & 1 & & & 1 & 1 & & 102 & 92 \\
\hline F. pennsylvanica & 2 & & & & & & & & 2 & \\
\hline Q. robur & & & 2 & 1 & 15 & 21 & 7 & 6 & 4 & \\
\hline T. cordata & & & & & 9 & 7 & & & 30 & 17 \\
\hline
\end{tabular}

Explanations: $\mathrm{L}$ - left side of avenue, $\mathrm{R}$ - right side of avenue.

\section{RESULTS}

Distances between trees and roadside were very diverse - ranging from 0.5 to $12 \mathrm{~m}$ (Table 2). These distances were variable not only between different avenues, but also inside one side of the avenue (e.g. left side of Kocury-Brusno avenue: 1-11 m). Distance between trees along the avenue was also very variable - ranging from 1 to $174 \mathrm{~m}$, due to natural gaps, cuttings and private roads. The highest range of distances between trees was found in Brusno-Popielewo tree avenue (4-174 $\mathrm{m})$, and lowest - in planned nature monument Kocury-Brusno avenue (2-34 m).

All studied tree avenues (excluding fragment of Kocury-Brusno avenue) were single row, two-sid- ed and formed from different tree species: Acer platanoides, A. pseudoplatanus (including cultivar $A$. pseudoplatanus 'Purpureum'), Betula pendula, Fagus sylvatica, Fraxinus excelsior, F. pennsylvanica, Quercus robur and Tilia cordata. In total, 1488 trees were identified and measured. Only two species - Acer platanoides and A. pseudoplatanus occurred in all studied avenues. Fraxinus excelsior and Quercus robur were recorded in four avenues, Tilia cordata, Betula pendula, Acer pseudoplatanus 'Purpureum' and Fraxinus pennsylvanica occurred in two avenues and Fagus sylvatica occurred in only one avenue. The species composition in the studied avenues was different (Fig. 2, Table 3). In Brusno-Popielewo, as well as in Kocury-Brusno the two main tree species were Acer platanoides and Fra-
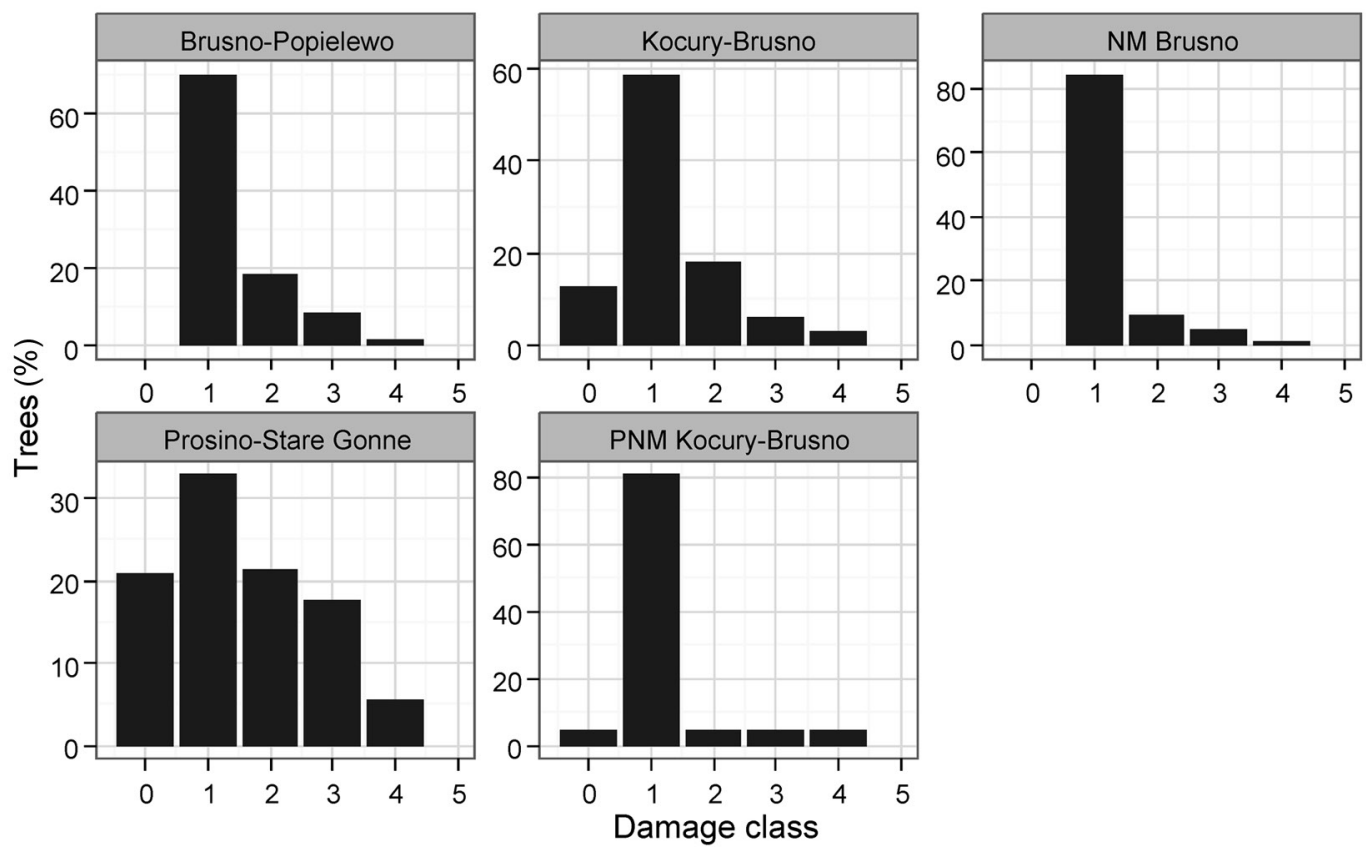

Fig. 3. Percentage of trees in each particular stem damage class in studied avenues of north-eastern part of the Drawski Landscape Park

Explanations: PNM - planned nature monument, NM - nature monument, 0 - no damages on tree stem, 1 - damages up to $10 \%$ of circumference, 2 - damages on 11-25\%, 3 - damages on $26-50 \%, 4$ - damages on $51-75 \%, 5$ - damages over $75 \%$ of circumference. 

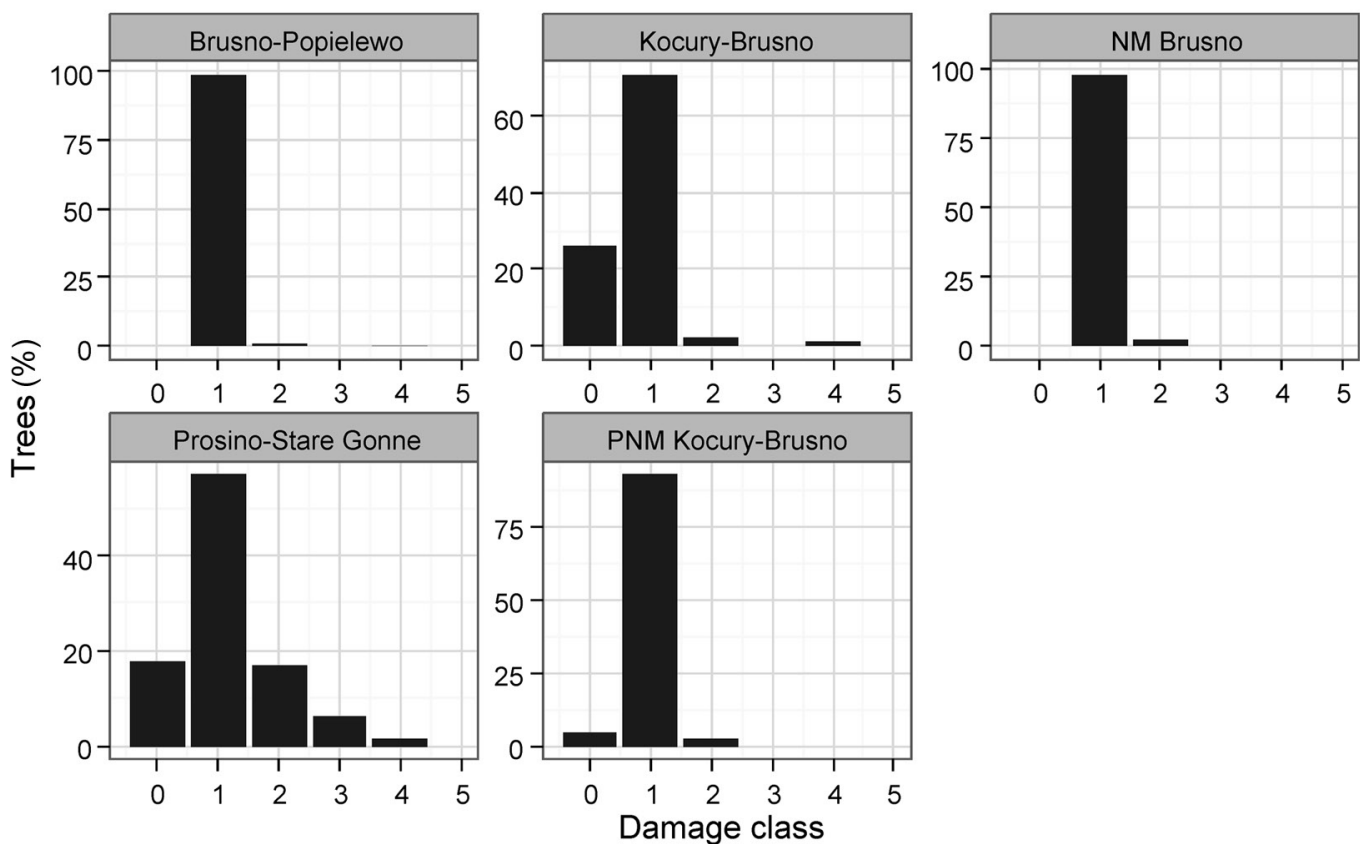

Fig. 4. Percentage of trees in each particular foliage damage class in the studied avenues of north-eastern part of the Drawski Landscape Park

Explanations: PNM - planned nature monument, NM - nature monument, 0 - no damages, 1 - damages up to $10 \%$ of leaf area, 2 - damages on $11-25 \%, 3$ - damages on $26-50 \%, 4$ - damages on $51-75 \%, 5$ - damages over $75 \%$ of leaf area.

xinus excelsior. In 'Brusno' tree avenue the most frequent species were Acer pseudoplatanus and Quercus rubra, with an admixture of Tilia cordata. In planned nature monument Kocury-Brusno tree avenue and in Prosino-Stare Gonne avenue most trees were Acer platanoides and A. pseudoplatanus, whereas in Prosino-Stare Gonne there was an admixture of Betula pendula.
Overall health condition of studied trees was good. In all the studied avenues the most frequent class of stem damage was 1 (up to $10 \%$ of damaged circumference); in four of five avenues this class consisted of more than $50 \%$ of observations, with the exception of Prosino-Stare Gonne, where it was $32.9 \%$, but 0 class (no damages) in this avenue was $20.8 \%$. Higher classes (3-5) never exceed $20 \%$ of
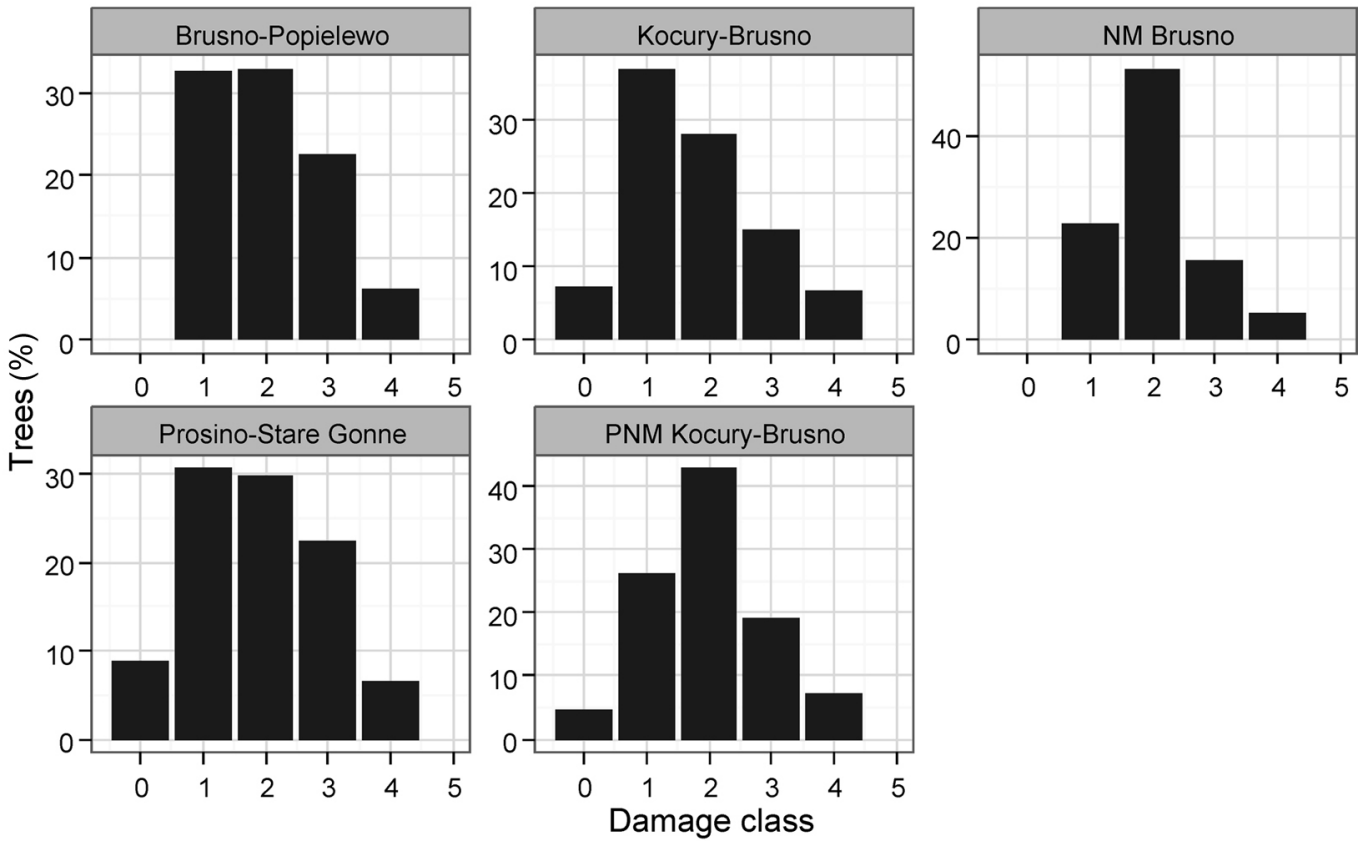

Fig. 5. Percentage of trees in each particular crown branches damage class in studied avenues of north-eastern part of the Drawski Landscape Park

Explanations: PNM - planned nature monument, NM - nature monument, 0 - no damages, 1 - damages up to $10 \%$ of branches, 2 - damages on $11-25 \%, 3$ - damages on $26-50 \%, 4$ - damages on $51-75 \%, 5$ - damages over $75 \%$ of branches. 


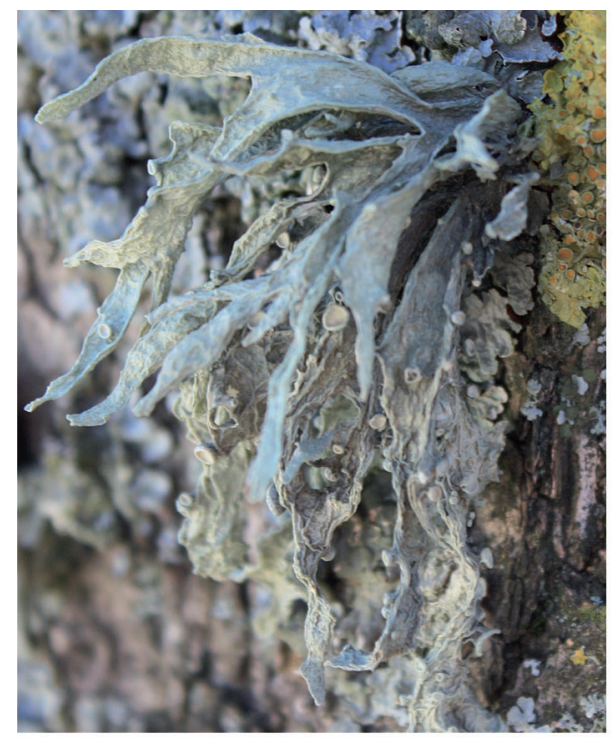

${ }^{*}$ Ramalina fraxinea

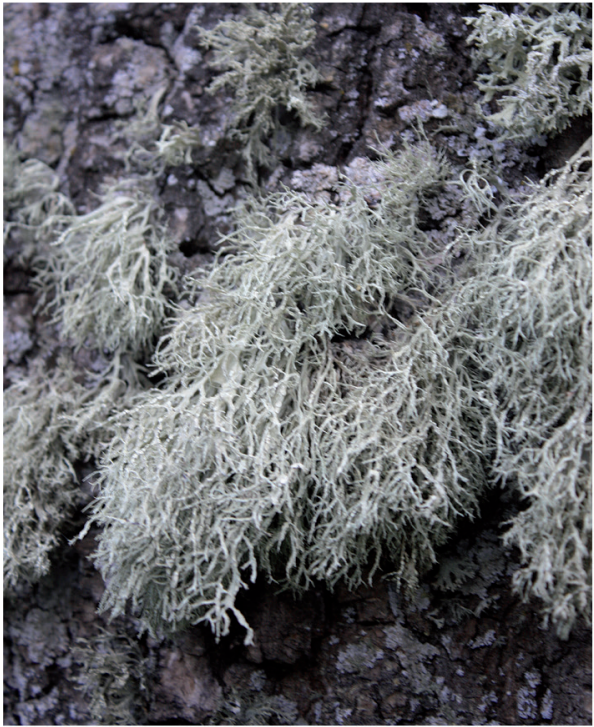

${ }^{* *}$ Ramalina farinacea

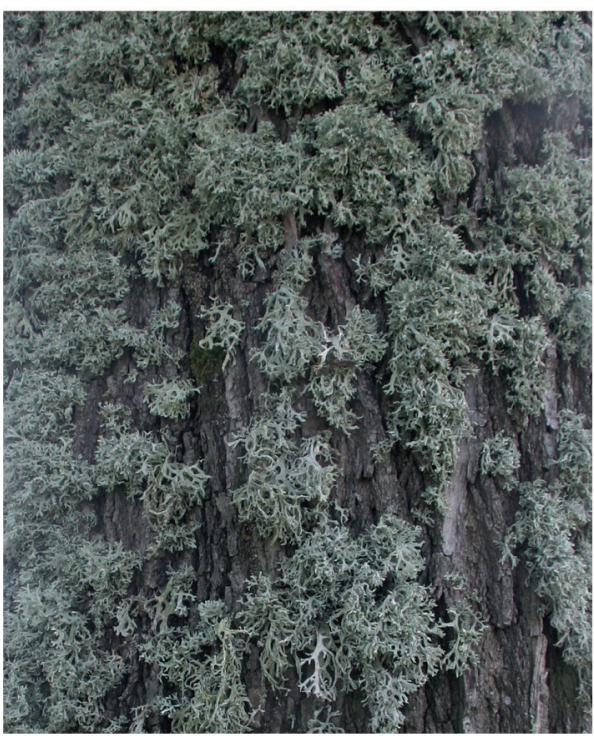

${ }^{* * * E v e r n i a ~ p r u n a s t r i ~}$

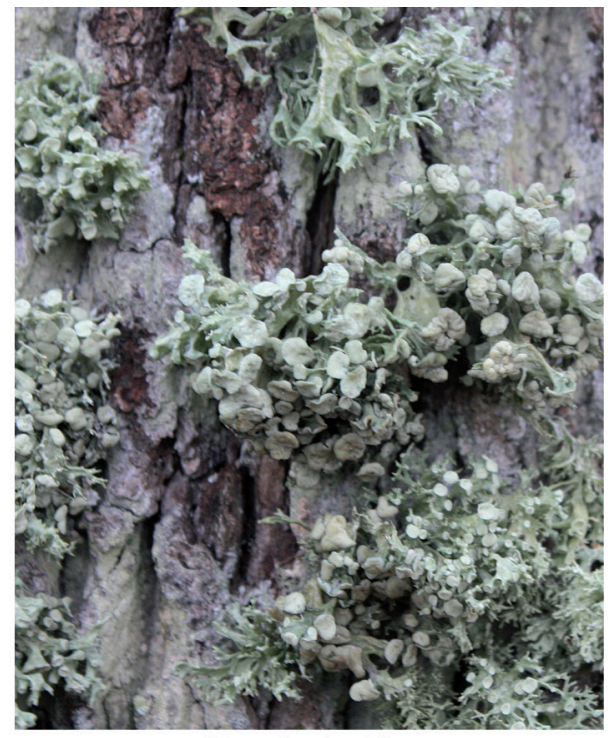

*Ramalina fastigiata

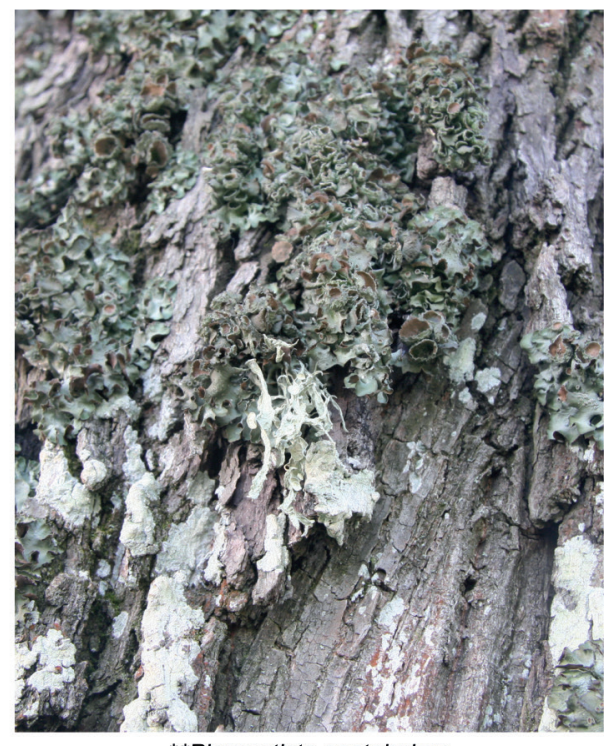

**Pleurosticta acetabulum

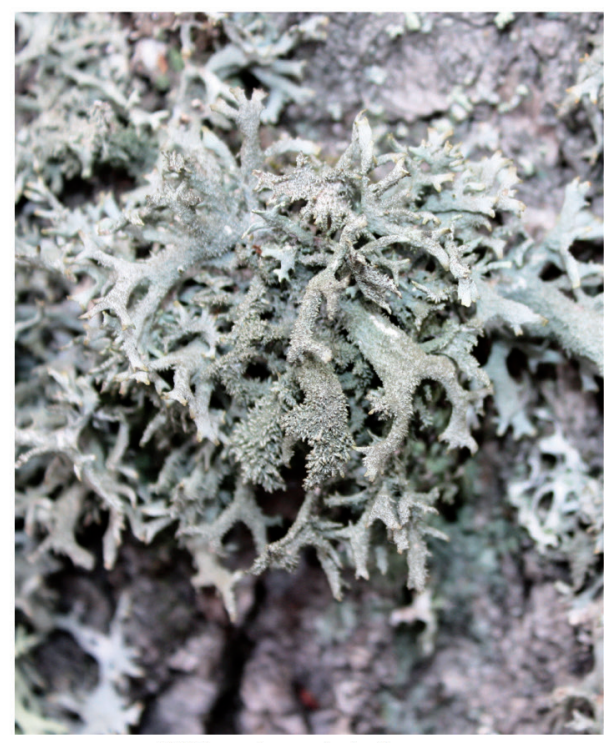

${ }^{* * * P}$ seudevernia furfuracea

Fig. 6. Species of epiphytic lichens rare and/or protected by Polish law found on trees in the studied tree avenues: * strictly protected, ${ }^{* *}$ - partially protected, ${ }^{* * *}$ - rare species, legally protected in 2014 (phot. R. Grzegorczyk) 
trees (Fig. 3). The most frequent class of foliage damage in all studied avenues was 1 (57-98.9\% of trees). Higher classes (3-5) were rarely recorded, e.g. in Prosino-Stare Gonne $(8.5 \%)$ and in Kocury-Brusno (1\%) (Fig. 4). Branches health differed among the studied avenues, however most trees had low class of damage (1 and 2). The largest occurrence of trees with visible branch damage (3-5) were recorded in Brusno-Popielewo and Prosino-Stare Gonne avenues (Fig. 5).

DBH range for studied trees was very variable, in studied avenues both young and old trees grew. From 1488 examined trees, DBH of 275 (18.5\%) trees was higher than minimal qualifying diameter to be classed as a nature monument according to RuciŃski's (1998). The majority of these trees were Acer platanoides (130 trees, DBH from 71 to $136 \mathrm{~cm}$ ) and A. pseudoplatanus (86 trees, DBH from 71 to 156 $\mathrm{cm})$. Kocury-Brusno and Brusno-Popielewo avenues contained 32 trees of Fraxinus excelsior with monumental diameters (DBH from 81 to $124 \mathrm{~cm}$ ). Several monumental sized Quercus robur trees were recorded in Brusno and Kocury-Brusno avenues (12 trees, DBH range from 96 to $155 \mathrm{~cm}$ ). In Prosino-Stare Gonne and Kocury-Brusno avenues nine trees of Betula pendula with diameters exceeding monumental dimensions were recorded (DBH from 66 to $79 \mathrm{~cm}$ ). In 'Brusno' and Kocury-Brusno avenues there were 12 Tilia cordata trees with DBH higher than minimal qualification size as a monument of nature $(\mathrm{DBH}$ from 98 to $165 \mathrm{~cm}$ ).

Epiphytic lichens were present growing on a number of trees in the studied avenues. During the field investigation, six valuable species of epiphytic lichens were found: Ramalina fastigiata (Pers.) Ach. and Ramalina fraxinea (L.) Ach.) - these are strictly protected by Polish law, Pleurosticta acetabulum (Neck.) Elix \& Lumbsch and Ramalina farinacea (L.) Ach. with partial protection according to Polish law and Evernia prunastri (L.) Ach. and Pseudevernia furfuracea (L.) Zopf. - considered relatively rare species in Poland and legally protected in 2014 (Fig. 6).

\section{DISCUSSION}

The studied avenues are two-sided, one-row arrays of trees, composed of more than one tree species. Kubus (2008) claims that this type of roadside avenue is the most frequent in West Pomerania region. Studies conducted recently in northern Poland have shown that the most frequent tree species forming roadside avenues are Acer platanoides, Fraxinus excelsior, Quercus robur and Tilia cordata (KUBus 2008, KoŁodziej et al. 2009, LiżEwsKa \& ZWierowicz 2009, Juźwiak 2012, SzMigiel-Franz \& TyszKo-ChMielowiec 2012). Although Kubus (2008) claimed that in West Pomerania Fraxinus excelsior is rare in roadside avenues, in our study this species occurred in four of five studied avenues and in two of them - Brusno-Popielewo and Kocury-Brusno $49.6 \%$ and $39.6 \%$ of trees present were this species, respectively.

From the assessed parts of trees, crowns had the worst health condition. The most damaged tree species and component were Fraxinus excelsior crowns, damages were caused by fungal diseases, mainly by ash dieback resulting from Chalara fraxinea infection (Kowalski 2001, Kowalski \& CZeKaj 2010, KuBus 2010, WicZYŃsKA et al. 2013). Although LiżEwSKA \& ZWIERowicz (2009) found that improper cutting of branches caused most crown damage, in studied areas only some trees were treated in this way and cuttings were conducted properly. Foliage damage was mainly caused by Rhytisma acerinum, which also occurred in West Pomerania avenues studied by KuBUs $(2008,2010)$. However, condition of foliage was good and no more than $10 \%$ of leaf area was damaged. Trunk damages were highest in trees growing closest to the roadside, and were mostly caused by agriculture vehicles. GAMRAT et al. (2011) also highlighted this factor as an important threat for trees in roadside avenues in Suchań and Dobrzany communities.

Two hundred and seventy-five trees with monumental diameters, as well as six species of rare and/or protected lichens occurred in studied avenues showing the important conservation value of such avenues. Polish roadside avenues face a myriad of threats, resulting from ineffective legislation and unjustified maintenance and road and utilities construction (Szmigiel-Franc \& TYszko-Chmielowiec 2012, Podolska 2013). The avenues studied in this paper indicate that such avenues require conservation. Gaps should be complemented by trees typical for each avenue, to maintain continuity of avenues, as ecological corridors. All studied avenues also should be protected by law as nature monuments.

\section{SUMMARY}

In north-eastern part of the Drawski Landscape Park there are roadside avenues which contain old, large and precious trees. The most frequent trees in studied avenues were Acer platanoides, Acer pseudoplatanus and Fraxinus excelsior. A high number of trees with monumental diameters occurred in studied avenues; $18.5 \%$ of trees which occurred in avenues were classified as monumental. Estimation of health status showed that most trees are in a good state of health (up to $10 \%$ damage). In all roadside avenues discontinuities were noticed, which are a result of lack of supplementary planting and improper treatments (unjustified cutting of trees). All the studied avenues have high landscape and environmental values, therefore should be protected as nature monuments. 


\section{ACKNOWLEDGMENTS}

We kindly thank Liam Donnelly (University College Dublin, Ireland) for valuable suggestions and linguistic revision of the manuscript. This study was partially supported by the Institute of Dendrology PAS, Kórnik, and the Department of Game Management and Forest Protection, Faculty of Forestry, Poznań University of Life Sciences.

\section{REFERENCES}

Gamrat R., Mtynkowiak E., Podlasiński M. (2011): Aktualny stan alei przydrożnych proponowanych do ochrony w dwóch sąsiadujących gminach Dobrzany i Suchań w województwie zachodniopomorskim. Ekologia i Technika 19(3A): 209-214.

JUźwIAK A. (2012): Lokalny program kształtowania zadrzewień przydrożnych dla gminy Mikołajki Pomorskie. Mikołajki Pomorskie - Kwidzyn. Opracowanie wykonane w ramach projektu „Drogi dla Natury - Kampania na rzecz zadrzewień". Urząd Gminy Mikołajki Pomorskie, Mikołajki Pomorskie.

KoŁodziej P., Fenyk A., Kuszewska K., Kamińska M., Kowalska A., Liśniański P., Wojtaszek A. (2009): Waloryzacja przyrodnicza alei przydrożnych województwa warmińsko-mazurskiego. In: K.A. Worobiec, I. Liżewska (eds). Aleje przydrożne. Historia, znaczenie, zagrożenie, ochrona. Wydawnictwo Borussia, Olsztyn: 133-137.

Kosmala M., RosŁon-Szeryńska E., Suchocka M. (2009): Metoda oceny kondycji drzew z uwzględnieniem bezpieczeństwa i uszkodzeń mechanicznych. Instytut Gospodarki Przestrzennej i Mieszkaniowej, Warszawa.

Kowalski T. (2001): O zamieraniu jesionów. Trybuna Leśnika 4: 6-7.

Kowalski T., Czekaj A. (2010): Symptomy chorobowe i grzyby na zamierających jesionach (Fraxinus excelsior L.) W drzewostanach Nadleśnictwa Staszów. Leśne Prace Badawcze 71(4): 357-368.

Kubus M. (2008): Godne prawnej ochrony aleje przydrożne na Pomorzu Zachodnim. Rocznik Dendrologiczny 56: 131-141.

Kubus M. (2010): Godne prawnej ochrony aleje przydrożne na Pomorzu Zachodnim, część 2. Rocznik Dendrologiczny 58: 71-78.

Kujawa A. (2012): Grzyby wielkoowocnikowe. In: P. Tyszko-Chmielowiec (ed.). Aleje - skarbnice przyrody. Praktyczny podręcznik ochrony alej i ich mieszkańców. Fundacja EkoRozwoju, Wrocław: 93-102.

LIPNICKI L. (2003): Porosty Borów Tucholskich. Park Narodowy „Bory Tucholskie”, Charzykowy.

LiżewsKa I., ZWIERowicz M. (2009): Aleje przydrożne - dziedzictwo historyczne, stan zachowania, ochrona. In: K.A. Worobiec, I. Liżewska (eds). Aleje przydrożne. Historia, znaczenie, zagrożenie, ochrona. Wydawnictwo Borussia, Olsztyn: 95-112 .

OCHRONA ŚRODOWISKA 2014 (ENVIRONMENT 2014). (2014): Główny Urząd Statystyczny (Central Statistical Office), Warszawa.

Oleksa A. (2012): Chronione porosty. In: P. Tyszko-Chmielowiec (ed.). Aleje - skarbnice przyrody. Praktyczny podręcznik ochrony alej i ich mieszkańców. Fundacja EkoRozwoju, Wrocław: 107-116 .

Oleksa A., Kadej M., Smolis A. (2012): Chronione owady. In: P. Tyszko-Chmielowiec (ed.). Aleje skarbnice przyrody. Praktyczny podręcznik ochrony alej i ich mieszkańców. Fundacja EkoRozwoju, Wrocław: 117-122.

Oleksa A., Ulrich W., GaWroński R. (2006): Occurrence of the marbled rose-chafer (Protaetia lugubris Herbst, Coleoptera, Cetoniidae) in rural avenues in northern Poland. Journal of Insect Conservation 10: 241-247.

OrŁowska B. (2012): Ptaki. In: P. Tyszko-Chmielowiec (ed.). Aleje - skarbnice przyrody. Praktyczny podręcznik ochrony alej i ich mieszkańców. Fundacja EkoRozwoju, Wrocław: 92-102.

Podolska A. (2013): Zadrzewienia liniowe w strefie podmiejskiej Wrocławia. Nauka Przyroda Technologie 7(2): \#28.

RuciŃski P. (1998): Motywy i kryteria uznawania tworów przyrody za pomniki. Las Polski 23: 7-10.

Szmigiel-Franc A., Tyszko-Chmielowiec P. (2012): Program drogi dla natury - dorobek i doświadczenie. In: P. Tyszko-Chmielowiec (ed.). Aleje - skarbnice przyrody. Praktyczny podręcznik ochrony alej i ich mieszkańców. Fundacja EkoRozwoju, Wrocław: 137-160.

UCHWAŁA nr XXXVII/499/14 Sejmiku Województwa Zachodniopomorskiego $z$ dnia 24 czerwca 2014 r. w sprawie Drawskiego Parku Krajobrazowego (Dz.U. z 2014 r., poz. 2919).

WiczyŃSKa K., HoRodecki P., JagodZí́sKi A.M. (2013): Stand structure and species composition in the 'Czmoń' nature reserve. Nauka Przyroda Technologie 7(4): \#69.

Witkoś-Gnach K., Tyszko-Chmielowiec P. (eds) (2014): Drzewa w krajobrazie. Podręcznik praktyka. Fundacja EkoRozwoju, Wrocław.

For citation: Grzegorczyk R., Sigiel-Dopierata A., DYDERSKI M.K., JAGODZIŃSKI A.M. (2015): Valuable roadside tree avenues in the north-eastern part of the Drawski Landscape Park. Steciana 19(2): 97-104. DOI 10.12657/steciana.019.011 